\title{
The Watercolors of Vincent Fossat: Art in the Service of Science
}

\author{
Les aquarelles de Vincent Fossat : L'art au service de la science
}

\author{
John R. Dolan ${ }^{1}$ \\ ${ }^{1}$ Sorbonne Université CNRS, Laboratoire d'Océanographie de Villefranche-sur-Mer, Station Zoologique, 06230 \\ Villefranche-sur-Mer, France, john.dolan@imev-mer.fr
}

\begin{abstract}
Vincent Fossat (1822-1891) was an artist who worked for the naturalist Jean-Baptise Barla for most his life. Fossat produced remarkable watercolors of mushrooms, flowers and fish for Barla. The paintings served as documentation of Barla's specimens, recording their colors and living aspects. He also did lithographs for Barla's publications on mushrooms and orchids. Fossat's magnificent detailed watercolors have been preserved at the Musée d'Histoire Naturelle de Nice and periodically shown in local exhibitions but are little known outside Nice. Here an effort is made to introduce Vincent Fossat and his watercolors to a wide audience. A brief history of Fossat's private and artistic life is provided and examples of Fossat's watercolors are given.

KEYWORDS. scientific illustration, 19th century biology, mycology, botany, ichthyology.
\end{abstract}

\section{Introduction}

Vincent Fossat (1822-1891) produced hundreds of magnificent watercolors of natural history subjects- mushrooms, flowering plants and fish. His detailed paintings served as recordings of the living subjects, much as photographs do today. They were done for his long time employer, JeanBaptiste Barla, the renowned naturalist of Nice. Barla bequeathed the watercolors in 1896, among his very substantial donations to the Muséum d'Histoire Naturelle de Nice, which he had headed for many years. Long forgotten, they were 're-discovered' and brought to the attention of the public by Eugene Caziot when he assumed the direction of the Muséum d'Histoire Naturelle de Nice in 1912. He found them stored in boxes in the attic of the museum. Fossat's watercolors, never displayed in his lifetime, became known to be a precious holding by the Muséum (e.g. Isnard \& Cordier 1935) and, in honor of his artistic work, a street in Nice was named for him in 1923 (anon 1923). The watercolors have been periodically exhibited, but only in Nice and the surrounding cities. A special issue of the Annales du Muséum d'Histoire Naturelle de Nice published in $1996\left(\mathrm{n}^{\circ} 11\right)$, dedicated to Jean-Baptiste Barla, contains a dozen reproductions of Fossat's watercolors in all (e.g, Bauchot 1996; Trimbach 1996). Many were reproduced in a book on painters of the region of Nice (Defaÿ 1998), a book on the early naturalist of Nice (Fredj \& Meinardi 2007), and in a richly illustrated book on the holdings of the Muséum d'Histoire Naturelle de Nice (Chamagne Rollier \& Defaÿ 2013), and 3 illustrations in book on traditional fishing in the Mediterreanen Sea (Monot 2011). However, these publications are all in French, and most are out of print and held in only a few dozen libraries worldwide.

Interestingly, some biologists in recent years have used Fossat's depictions for their original purpose, which is showing what the organisms looked like in life. Figure 1 shows a Fossat painting of a deep sea fish prominent on the cover of a book on Mediterranean deep-sea ecosystems, several other of his illustrations of deep sea fish appear throughout the text (WWF/IUCN 2004), and a Fossat watercolor of a mushroom used as a cover illustration for an article on Barla's studies of mushrooms (Cuccuini 2009). However, to the general public, the watercolors of Vincent Fossat are largely unknown. The goal here is to provide an introduction to Vincent Fossat's watercolors. First, a brief sketch of his life will be given based largely on the accounts given in Defaÿ (1998) and 
Chamagne Rollier \& Defaÿ (2013) as well personal communications from Jöelle Defaÿ. A selection of his watercolors will follow to showcase the qualities and ranges of his scientific illustrations.

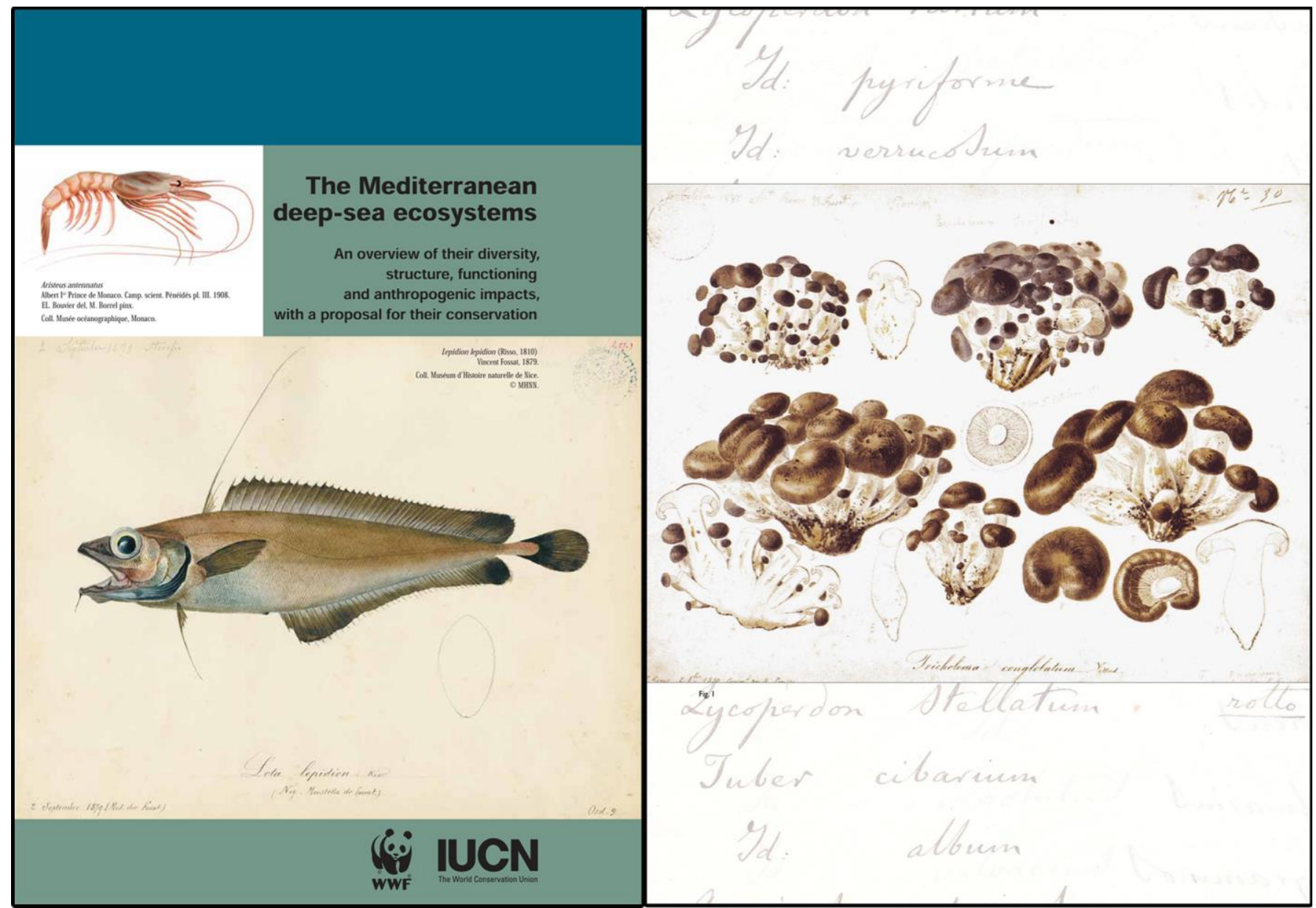

Fig. 1. Fossat's watercolors used in scientific publications in recent years. Right panel: the cover of a 2004 book on deep sea ecosystems of the Mediterranean Sea (WWF/IUCN 2004) featuring his 1879 watercolor of the deep sea fish Lepidion lepidion. Left panel: Cover illustration of a 2009 article (Cuccuini 2009) on

Barla's contributions to mycology featuring Fossat's 1880 watercolor of the mushroom Pyophyllum fumosum.

\section{The private and artistic life of Vincent Fossat}

Very little is known about Fossat's private life. A short account, based on municipal archive records (Beltrutti 1996a), provides the only certain information available. The archives state that Vincent Etienne Fossat (1822-1891) was part of a large family in Nice. He was the 7th of 9 children, born in rapid succession between 1814 and 1827 to Antoine Fossat and Camille Gras. Vincent Fossat was orphaned by age 20, and recorded as employed as a domestic servant in 1842 . He married Marie-Therese Bouis (marriage date unknown) and had two children, a daughter Anne, born in 1853, and a son Fortunée, born in 1854. He passed away at the age of 69 in 1891, survived by his wife, daughter, son and his employer Jean-Baptiste Barla. While we know little about his private life, we know with certainty even less about his training as an artist.

Eugene Caziot, the re-discover of Fossat's watercolors, stated that Vincent Fossat received training by Louis Garneray (1783-1857), a 19th century painter well known for portrayals of marine scenes, especially maritime battles (Caziot 1918). Unfortunately, Caziot provided no source for his statement. While there is documentary evidence that Garneray did indeed spend winters in Nice beginning in 1841 (Fighiera 1912), there are no accounts of Garneray's activities in Nice. Caziot's attractive, but unsubstantiated, statement that Fossat was taught by a master of marine scenes, has 
been repeated in subsequent accounts of Fossat's life (Delfaÿ 1998; Fredj \& Gaston 2007; Monat 2011; Chamagne Rollier \& Defaÿ 2013).

Regardless of how or where he trained, the first dated artwork by Fossat demonstrates indisputably that he was, by age 29, an accomplished artist. It is a lithograph dated 1850 and depicts a seaside scene in Nice. The work, "Le Quai du Midi et les Ponchettes" (Fig. 2), is held by the Musée Masséna in Nice. The Musée Masséna holds today 34 works by Fossat and sadly none are on display. The majority are watercolors but there are also drawings and lithographs. Unfortunately, only 7 of the 32 are dated, ranging from 1850 to 1880 , and most are unsigned. Many of the watercolors however show Fossat's obvious talent with watercolor e.g., Fig. 3.

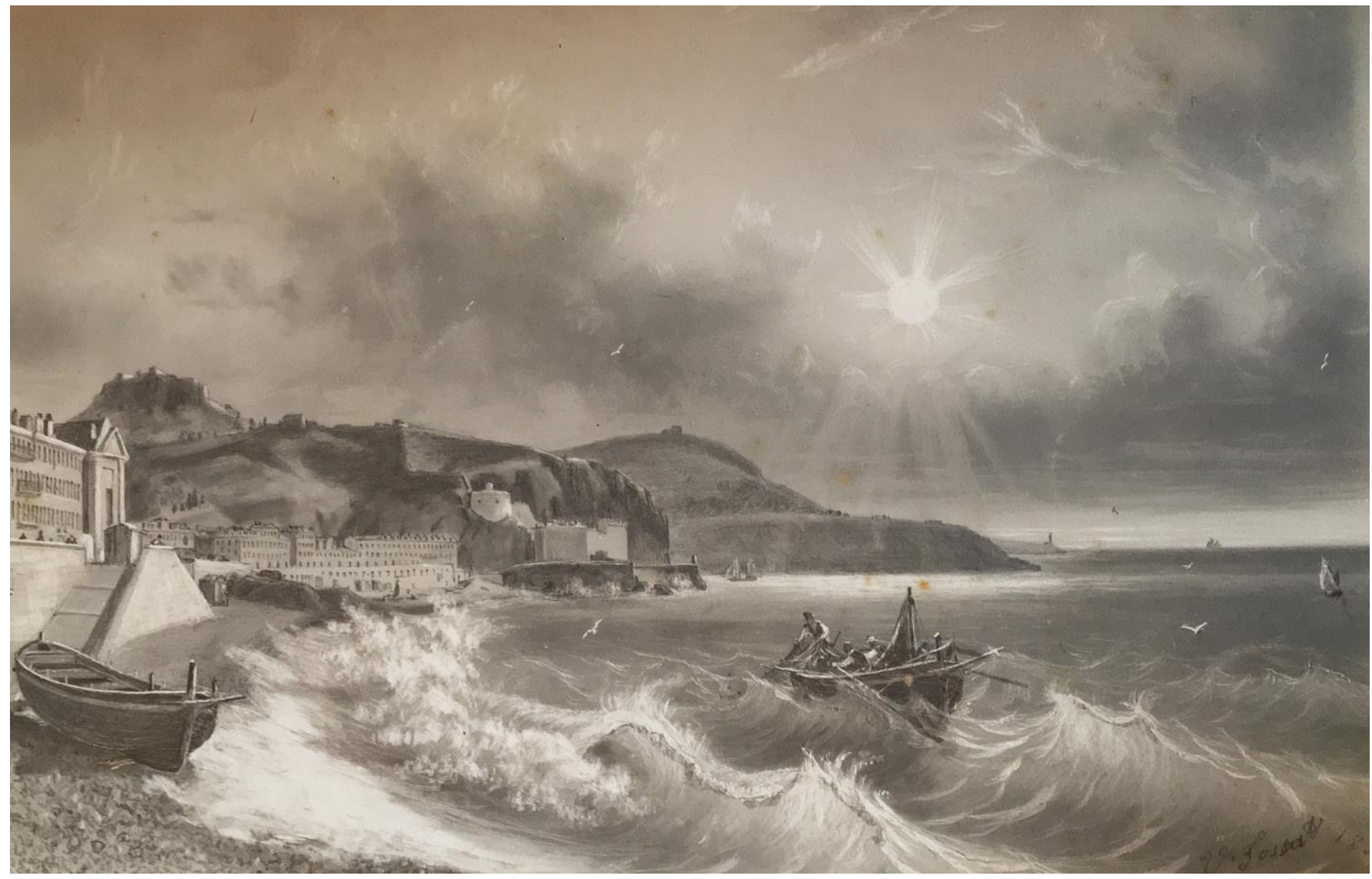

Fig. 2. Vincent Fossat's earliest known dated work (1850): Le Quai du Midi et les Ponchettes. Note the fine details shown in the seaside scene of Nice. The original (sized $18.5 \times 27.5 \mathrm{~cm}$ ) is held by the Musée Masséna and catalogued as a "lithographie rehaussée à la mine de plomb à divers endroits" (lithograph highlighted in diverse areas with a lead pencil). Reproduction courtesy of the Ville de Nice, Musée Masséna MAH-9201. 


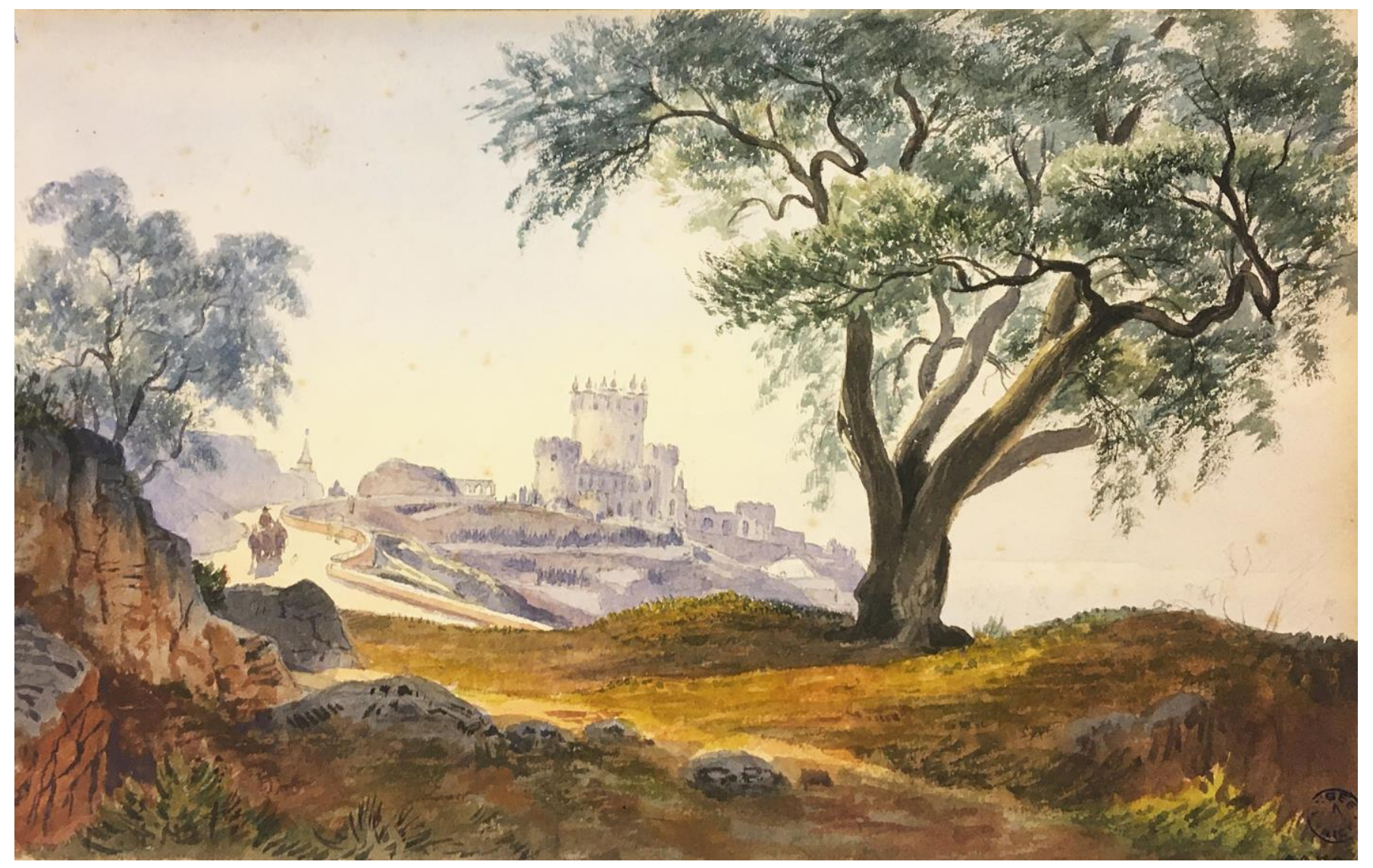

Fig. 3. The earliest dated watercolor by Vincent Fossat, "Le Château de l'Anglais (1856)" held by the Musée Massèna in Nice. The original is 13.3 × $20.7 \mathrm{~cm}$. Reproduction courtesy of the Ville de Nice, Musée Masséna, MAH-3270.

In 1853, Jean-Baptiste Barla, already an accomplished naturalist, hired Vincent Fossat as a scientific illustrator (Trimbach 1996). According to Trimbach, (whose account is based on the correspondence of Barla), the lithographer Xavier Caillol, who had done some lithographs for Barla himself, recommended Fossat to Barla. Vincent Fossat remained in Barla's employ for the rest of his life working as a painter of plaster models of mushrooms, a lithographer, and an illustrator. Over the many years they worked together, the two became inextricably linked. As Jöelle Defaÿ (1998) remarked, Barla would not have the scientific heritage he has today without Fossat's artistic contributions, and Fossat probably would not have lived as an artist without Barla's support.

Jean-Baptiste Barla was born in 1817 in Nice, just a few years before Vincent Fossat, and like Fossat, into a family with several children. However, Barla's family was of considerably different means than that of Fossat. Barla's father and grandfather were successful merchants, "Captains of Commerce", buying, transporting, and selling a variety of goods from salted cod and olive oil to seeds (Beltrutti 1996b). As the only male heir, he was destined to assume the family business and as a young man received a classical education. He was also given ample freedom to pursue his interest in natural history, primarily mushrooms. In 1851, at the age of 24 , he inherited the family business and assets totaling 278,000 "livres" (Fredj \& Meinhardi 2007), in today's currency, equal to several million Euros. Barla was then able to devote not only himself to his natural history pursuits but also to employ others to aid him in his efforts. He would devote his life and fortune to natural history. Barla became Director of the Muséum d'Histoire Naturelle de Nice in 1862. He succeeded JeanBaptiste Vérany who had founded the Muséum, the very first museum of Nice in 1846 (Thevenon 1990).

Barla hired Vincent Fossat in 1853. Fossat, at first, joined others in painting, in natural colors, the new plaster molds of mushrooms Barla had developed as means of creating permanent, life-like, full (C) 2021 ISTE OpenScience - Published by ISTE Ltd. London, UK - openscience.fr 
scale, specimens of the mushrooms he collected. Fossat's watercolors of freshly collected specimens served to show the painters the colors of the living specimen. However, Fossat's talents as a lithographer were soon exploited.

Barla's first illustrated monograph on mushrooms appeared in 1859, "Les Champignons de la Province de Nice et Principlement les Especes Comestibles, Suspectes ou Vénéneuses Dessinés d'Apres Nature et Décrits" (The Mushrooms of the Province of Nice, Principally the Species Edible, Suspect or Poisonous, Drawn from Nature and Described). It was illustrated with 48 lithographs, 45 of which were by Fossat. All of Barla's subsequent monographs would be illustrated primarily with Fossat's lithographs. In all, Barla's publications (Barla 1859, 1868, 1876, 1888, 1889a,b, 1890, 1892) contain 172 lithographs, and Fossat produced 168 of them. For 31 of the lithographs, Fossat is credited as sole artist of the original illustration and the lithograph. An example of a watercolor by Fossat, the lithograph stone on which Fossat drew elements from the watercolor, and the final, printed and hand colored plate are shown in figure 4. Remarkably, all of these elements are preserved in the Muséum d'Histoire Naturelle de Nice.

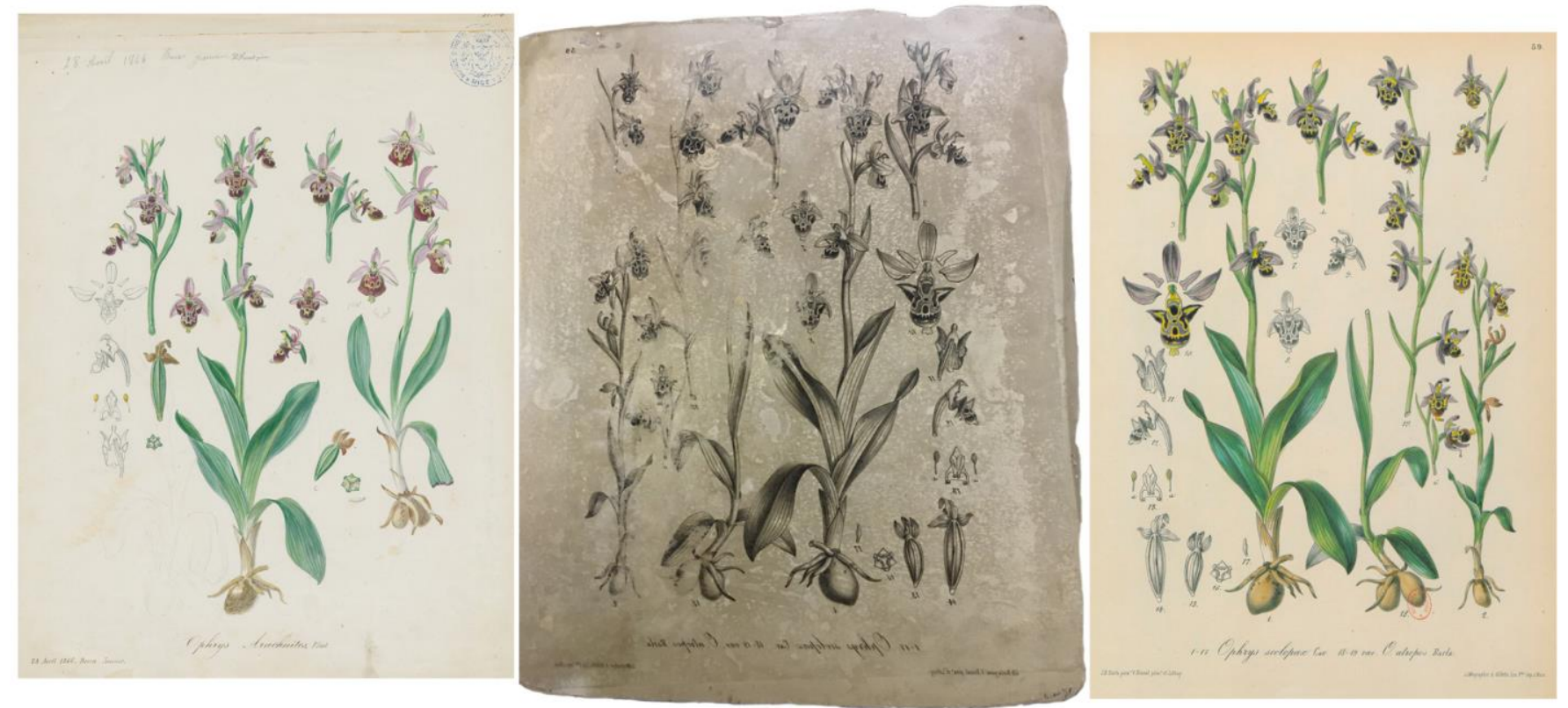

Fig. 4. The left panel is the 1866 water color by Fossat, the middle panel is image of Fossat's drawing on the lithograph stone used to print a black on white image, and the finished hand colored plate (plate 59 from Barla 1868) is shown in the right panel.

It appears that, for Barla, Fossat's watercolors were destined to record living aspects of organisms and to be used to produce images, as in the lithographs, or models to guide the painting of the plasters casts of mushrooms. 838 of his watercolors held by the Muséum d'Histoire Naturelle de Nice are inventoried (and can be seen in small format images) in the 'Joconde' website of the French Ministry of Culture by using the search term: Fossat Vincent.

http://www2.culture.gouv.fr/documentation/joconde/fr/pres.htm

Examining Fossat's production of watercolors year-by-year shows that the subjects of Fossat's watercolors varied with time, likely corresponding to shifts in Barla's interests (Fig. 5). Fossat painted mushrooms throughout his time with Barla, but in relatively small numbers. He produced a total of 133 paintings of mushrooms over a period of 35 years. Flowering plants were Fossat's subject from the late 1860 's to the early 1870 's, correspondingly roughly to the era of Barla's monograph on orchids (Barla 1868). Oddly enough, most of Fossat's watercolors were of fish from the sea near Nice. They represent the largest number of works (over 300) and were produced from 
the late 1870 's to the early 1880 's but were never used in any of Barla's publications. Barla never published on fish. One can only speculate that Barla had a project on fish in mind in the late 1870's but later dropped the subject to return to his favorite topic of mushrooms. Alternatively, perhaps Barla simply allowed Fossat the freedom to choose his own subjects and Fossat returned to his early subject, the sea.

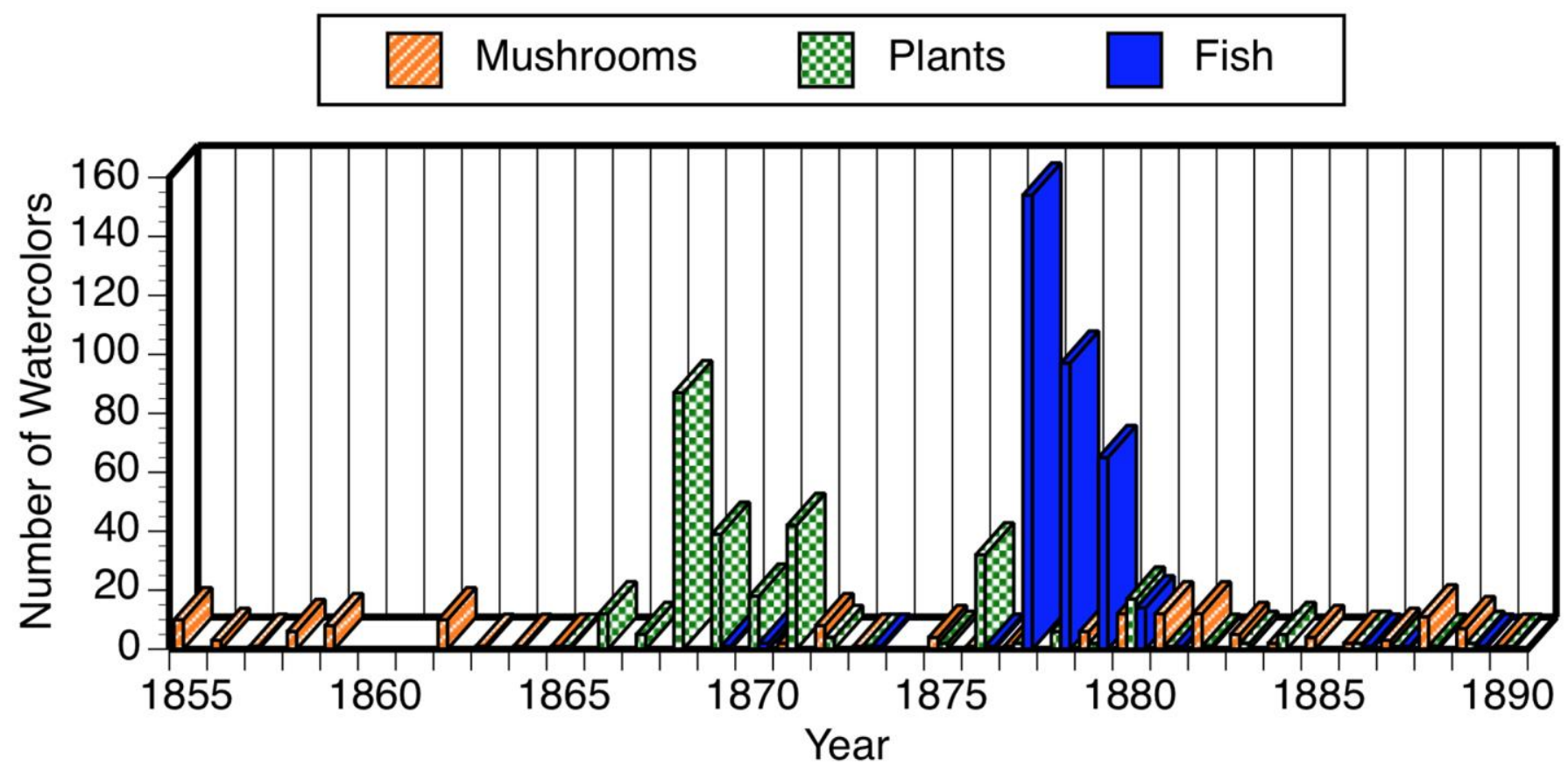

Fig. 5. The number of watercolors produced by Fossat by year and subject based on inventory data from the Joconde website: (http://www2.culture.gouv.fr/documentation/joconde/fr/pres.htm).

Fossat's production of watercolors of fish was truly remarkable. No contemporary accounts of his methods exist. The earliest appears to be in a 1914 article on the first exhibition of his fish watercolors at the Muséum d'Histoire Naturelle de Nice in December of 1913, not long after their 're-discovery' by Caziot (Lavagna 1914). The article states that Fossat went to the beach to meet the fishermen that were bringing ashore their catch of the day, still living. On site Fossat would then paint from life. Unfortunately, the fidelity of the article can be questioned as it gives Fossat's death date as 1871, a full 20 years before his actual death. Nonetheless, the image of Fossat painting freshly caught fish on the beach is undeniably attractive. The artist Franck Rainaut's view of such a scene is shown Fig. 6. However, it is difficult to imagine that Fossat could have produced his watercolors that included fine anatomical details on site. Furthermore, some watercolors show multiple specimens collected on different dates. Thus he would have had to bring the painting of the first specimen with him to the shore, hoping to collect another. It appears likely that Fossat's 'field work' was simply to record the colors and overall aspect of the living fish and the final, detailed painting was done back at the Muséum with the specimen in hand. In this regard it should be pointed out that Fossat noted on his paintings the date the specimen depicted was collected, not the date of the painting. Presumably, the painting would have been done soon after the specimen was collected, using a fresh fish so to speak, as fish unpreserved, or even preserved in alcohol, are usually distorted. 


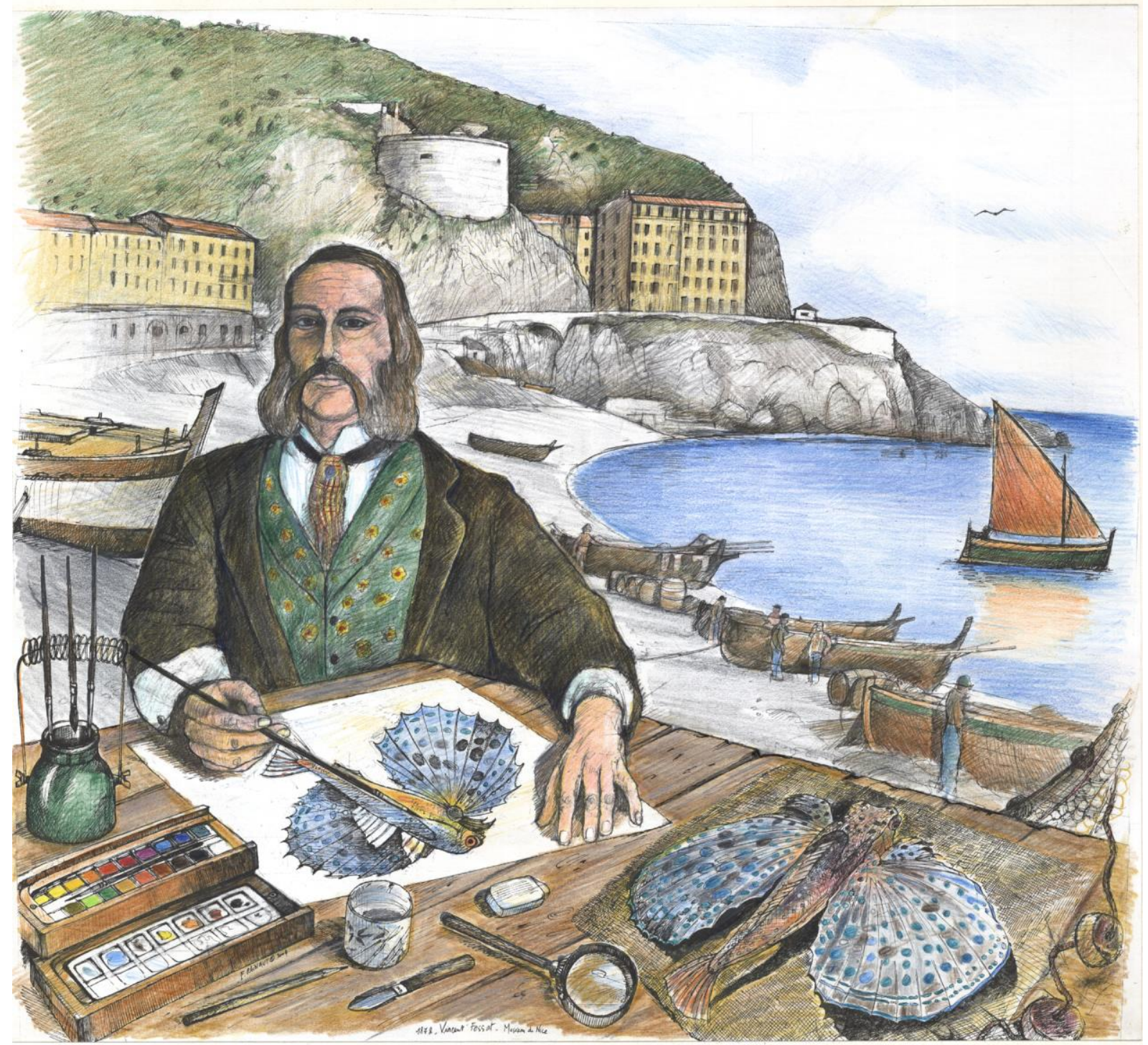

Fig. 6. 'Frank Rainaut's vision of Vincent Fossat at work in Nice near the same beach as that shown in Fossat's 1850 lithograph (Fig. 2). The mixed media work of $55 \mathrm{~cm}$ by $51 \mathrm{~cm}$ is titled "Vincent Fossat sur la plage des Ponchettes en 1878". Reproduced courtesy of Frank Rainaut, all rights reserved by the artist.

Regardless of where Fossat painted his watercolors of fish, his output was at times prodigious. A great number of watercolors were painted of specimens collected during the month of May alone in 1877. Figure 7 shows the number of specimens collected each day in May that were eventually depicted in a watercolor. Clearly he may have collected more specimens but we will never know. In any event, Fossat collected specimens nearly every day in May showing that he visited the fisherman often. If Fossat painted his watercolor the same day the specimen was collected, on some days he would have done 3 watercolors! 
May 1877

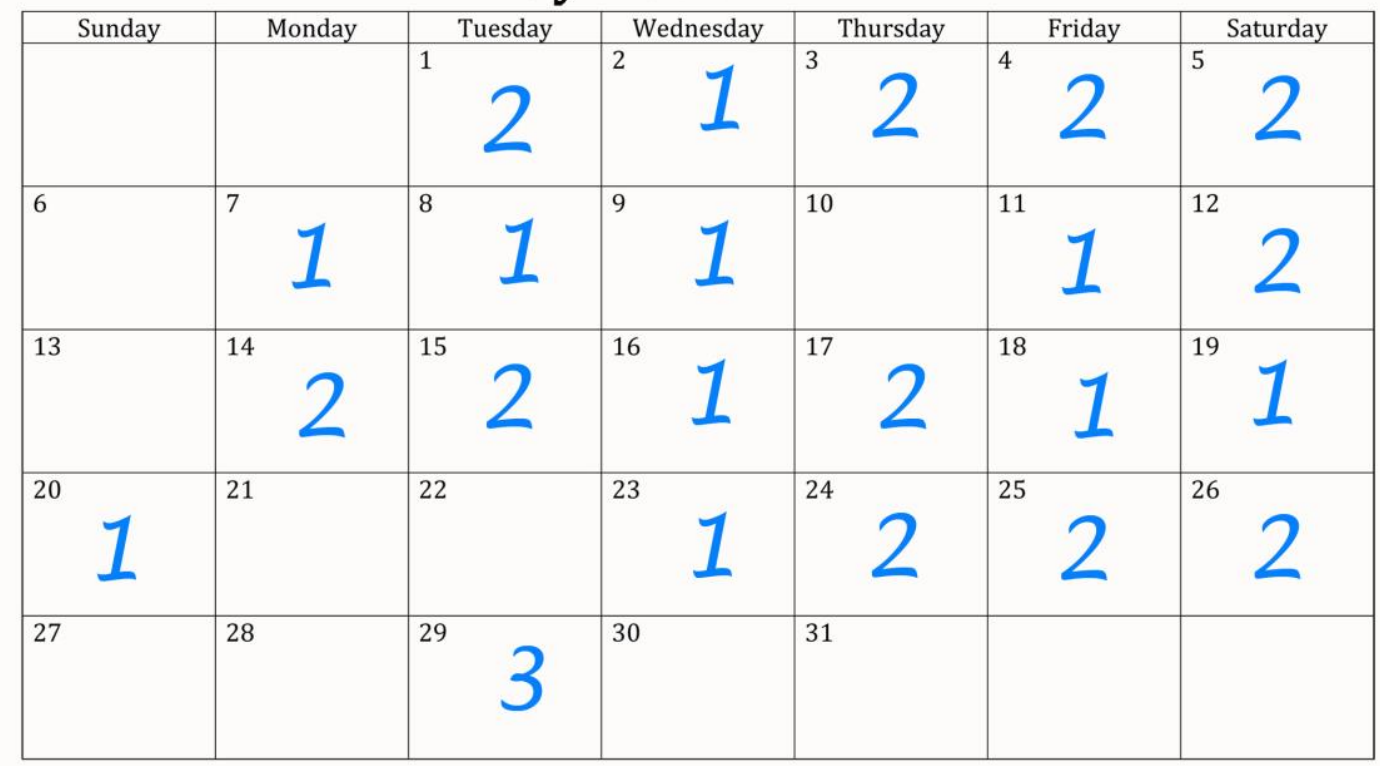

Fig. 7. Numbers of specimens of fish collected, day by day, in May 1977 by Vincent Fossat. Numbers shown are based on the dates of collection noted on the watercolors of fish collected in May 1877 from the works inventoried in the 'Joconde' website. Therefore, the numbers do not include any specimens not depicted by Fossat. Note that if Fossat painted specimens the day he collected them, on some days he produced 2 or 3 paintings.

Vincent Fossat's work was essential to Jean-Baptiste Barla, by Barla's own estimation. When Fossat died in 1891, Barla wrote to a letter to the journal Revue Mycologique to announce his passing (Anon. 1891). Barla's letter is said to have ended: "This irreparable loss has plunged me into a most extreme affliction because Vincent Fossat was for me not only a collaborator that contributed to enriching my collections with his numerous illustrations but he was also a loyal and old friend; thus his death robs me of any hope I had of continuing my work to its end. It would be nearly impossible to find another person with his talents as a watercolorist and lithographer and so I am obliged to suspend my work." (my translation).

\section{The Scientific Art of Vincent Fossat}

The following 15 pages provide a sampling of the watercolors of Vincent Fossat. The works were chosen to demonstrate the taxonomic breadth of his subjects and the remarkable quality of his paintings. They are a subjective selection drawn from the 835 watercolors which can be viewed (although in a small format) through the 'Joconde' website using the link provided above.

The selection provided is dominated by Fossat's watercolors of fish and echinoderms because these unpublished illustrations, in contrast to many of those of mushrooms and orchids, are not readily available in the digitized publications of Jean-Baptiste Barla. Links to two such publications are provided below.

Mushrooms:

$\underline{\text { https://books.google.fr/books?id=1hglAQAAMAAJ\&hl=fr\&source=gbs_navlinks_s }}$

Orchids: 


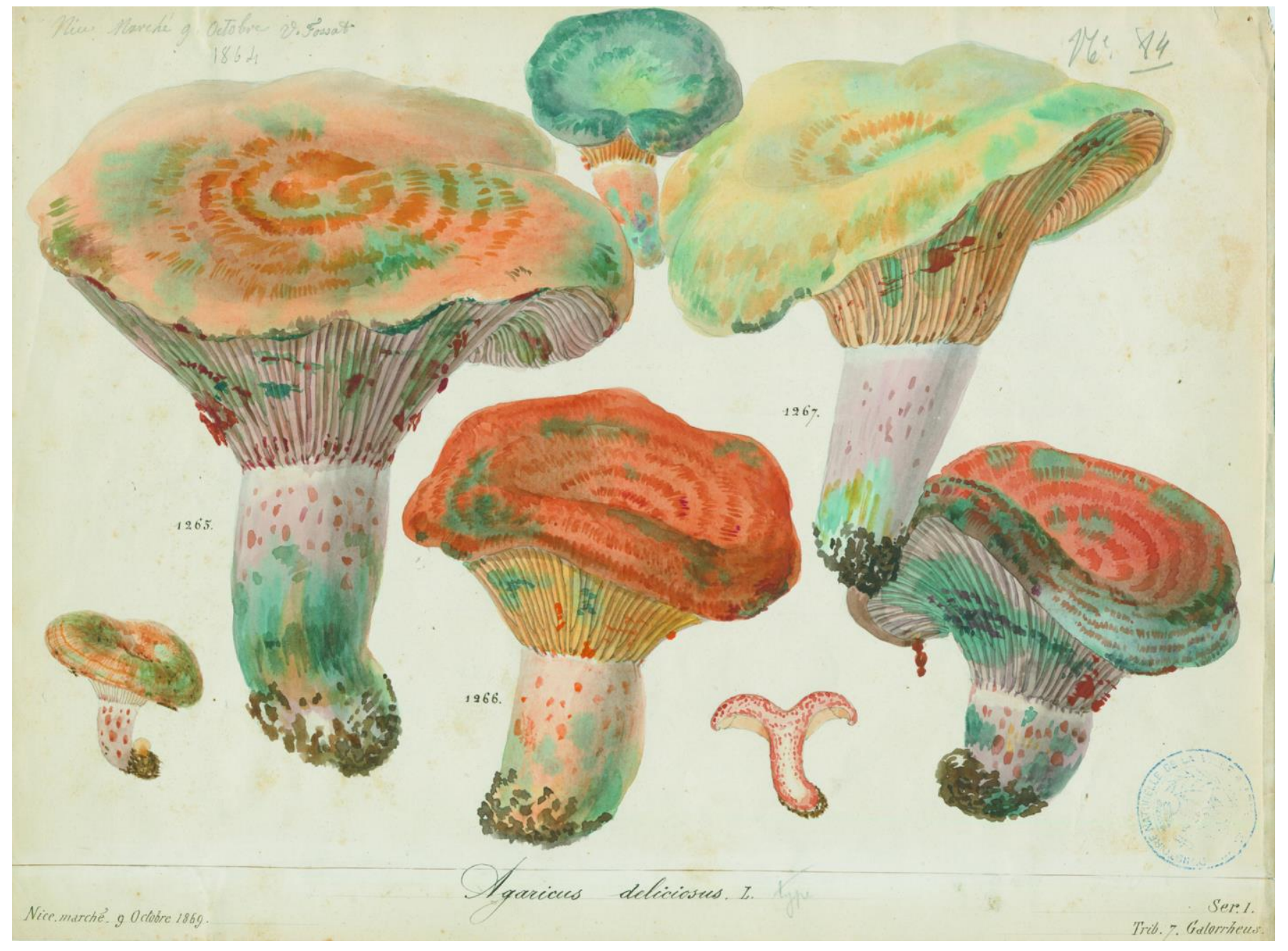

Fig. 8. The mushroom Lactarius deliciosus. The specimen was 'collected' from the marketplace of Nice on October 9, 1864. The actual dimensions of the painting are $26.5 \mathrm{~cm} \times 35 \mathrm{~cm}$. 


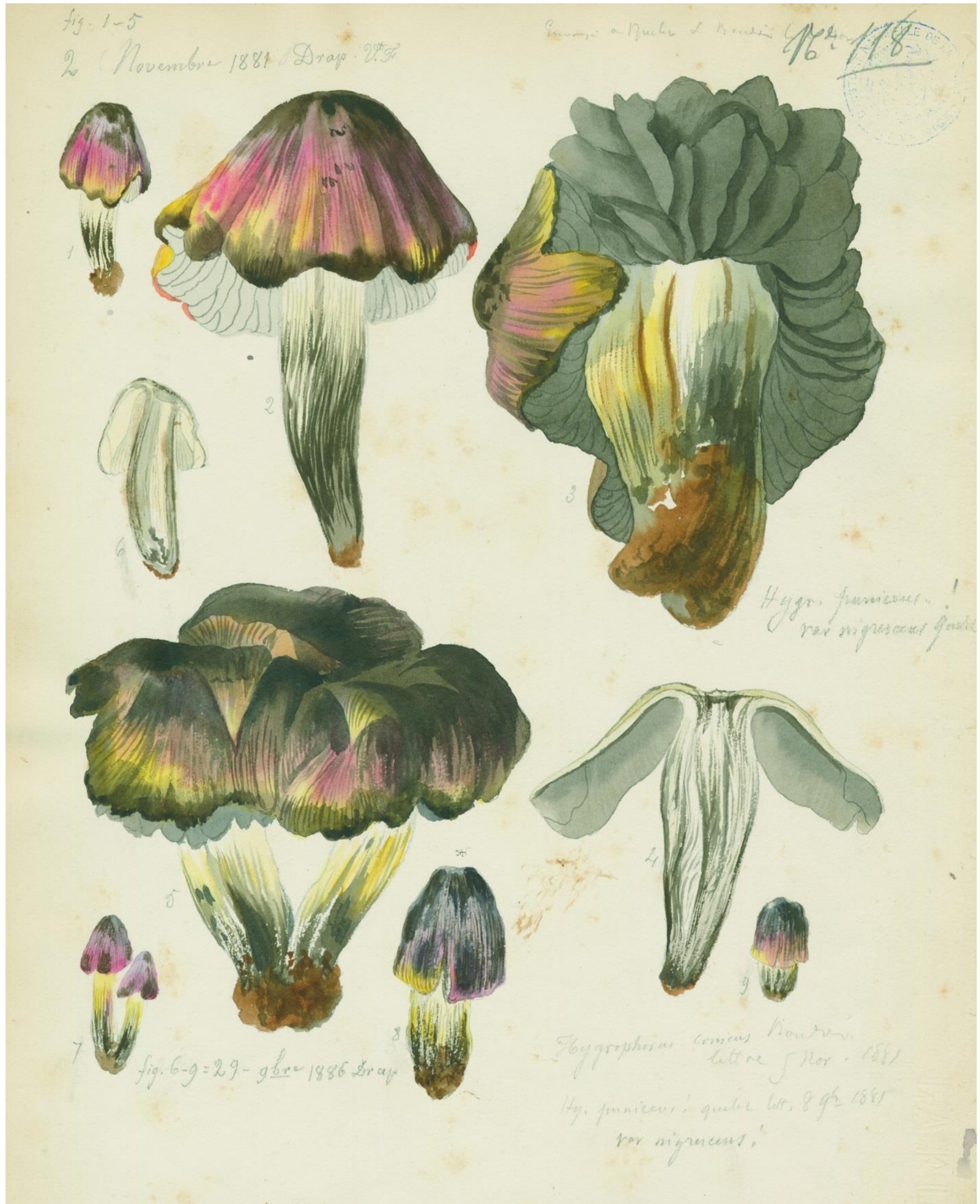

Fig. 9. The mushroom Hygrophorus conicus collected from Drap, a town inland from Nice, on November 02, 1881. The actual dimensions of the painting are $35 \mathrm{~cm} \times 27 \mathrm{~cm}$. 


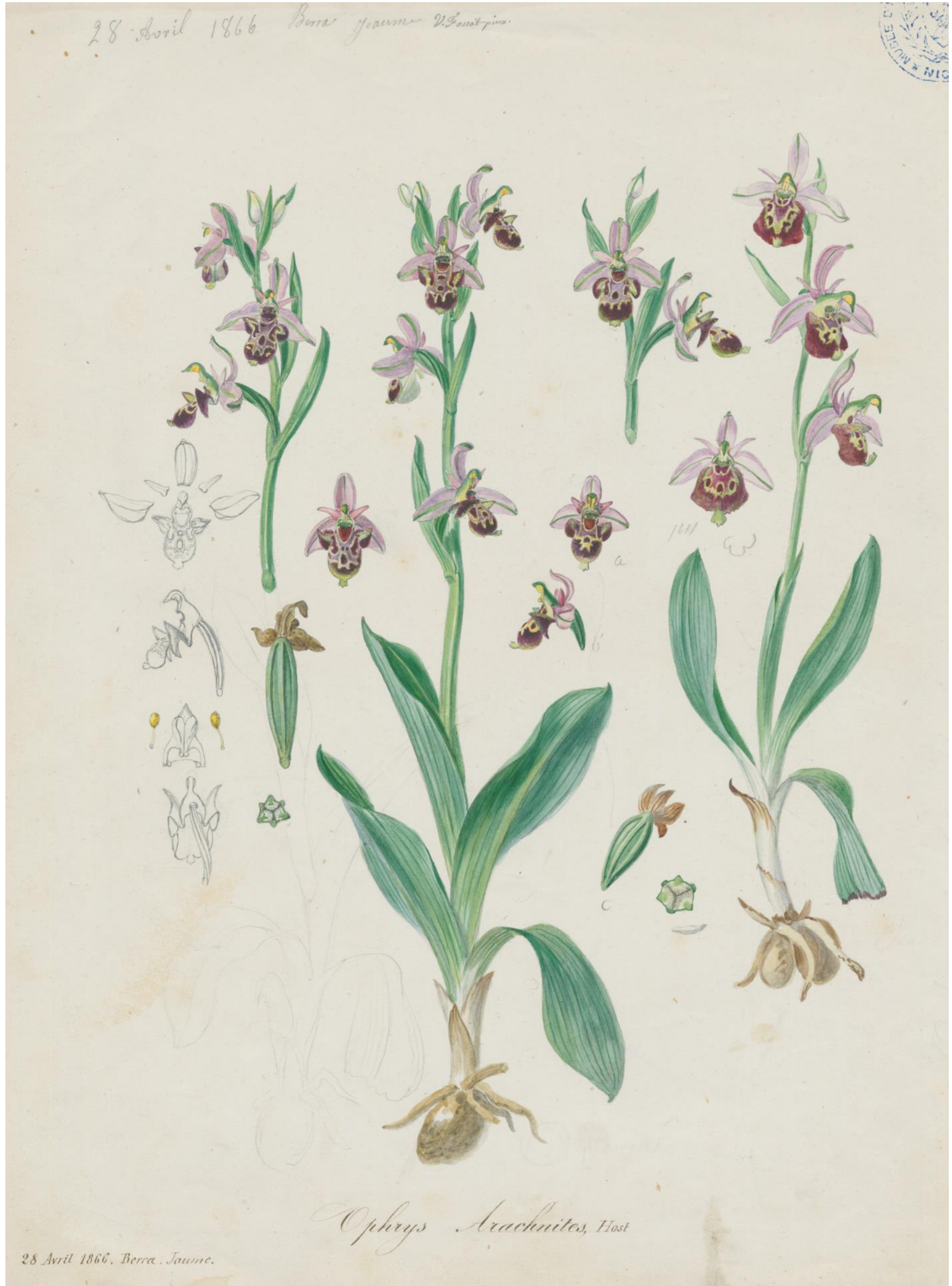

Fig. 10. The wild orchid Ophrys arachnites collected from the alpine town of Berre des Alpes on April 28, 1866. The painting served as the source for images in plate 59 in Barla's publication on orchids as shown in figure 3. The actual dimensions of the painting are $35.8 \mathrm{~cm} \times 27 \mathrm{~cm}$. 


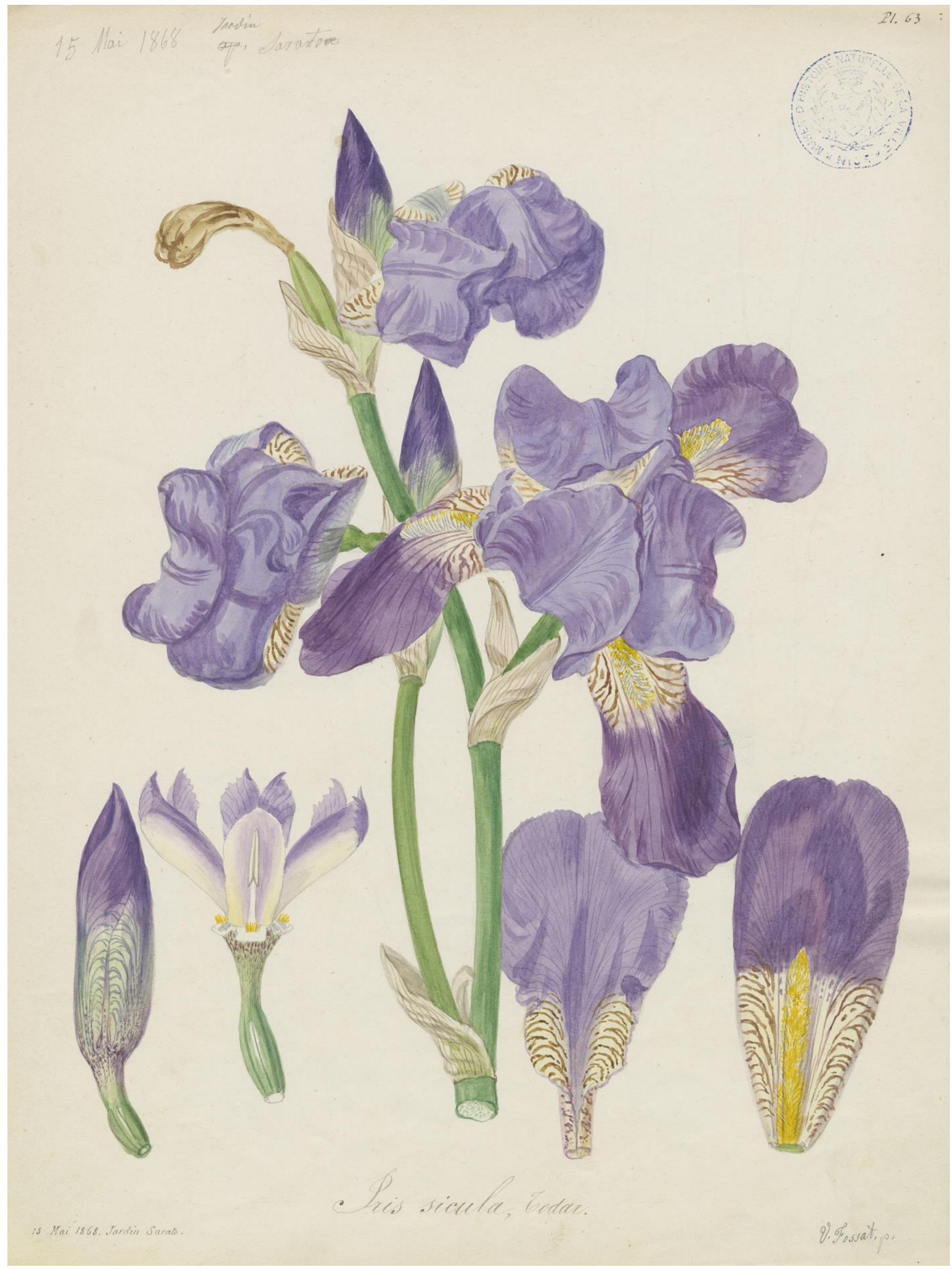

Fig. 11. The iris Iris sicula collected from the Sarato Garden (location unknown) on May 151868 . The actual dimensions of the painting are $35.8 \mathrm{~cm} \times 27 \mathrm{~cm}$. 


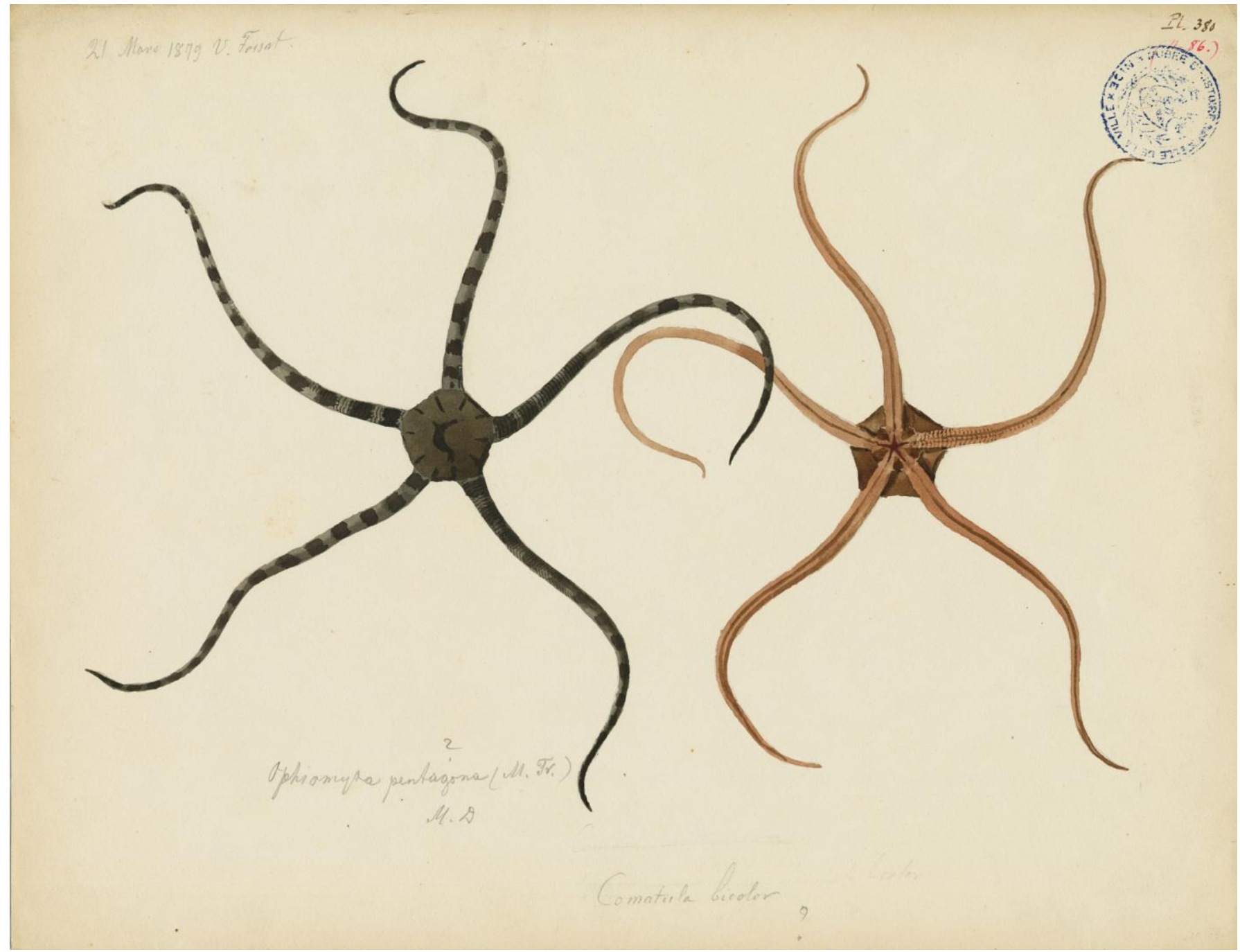

Fig. 12. The echinoderm Ophiomyta pentagona collected on March 21, 1879. The actual dimensions of the painting are $27 \mathrm{~cm} \times 35.2 \mathrm{~cm}$. 


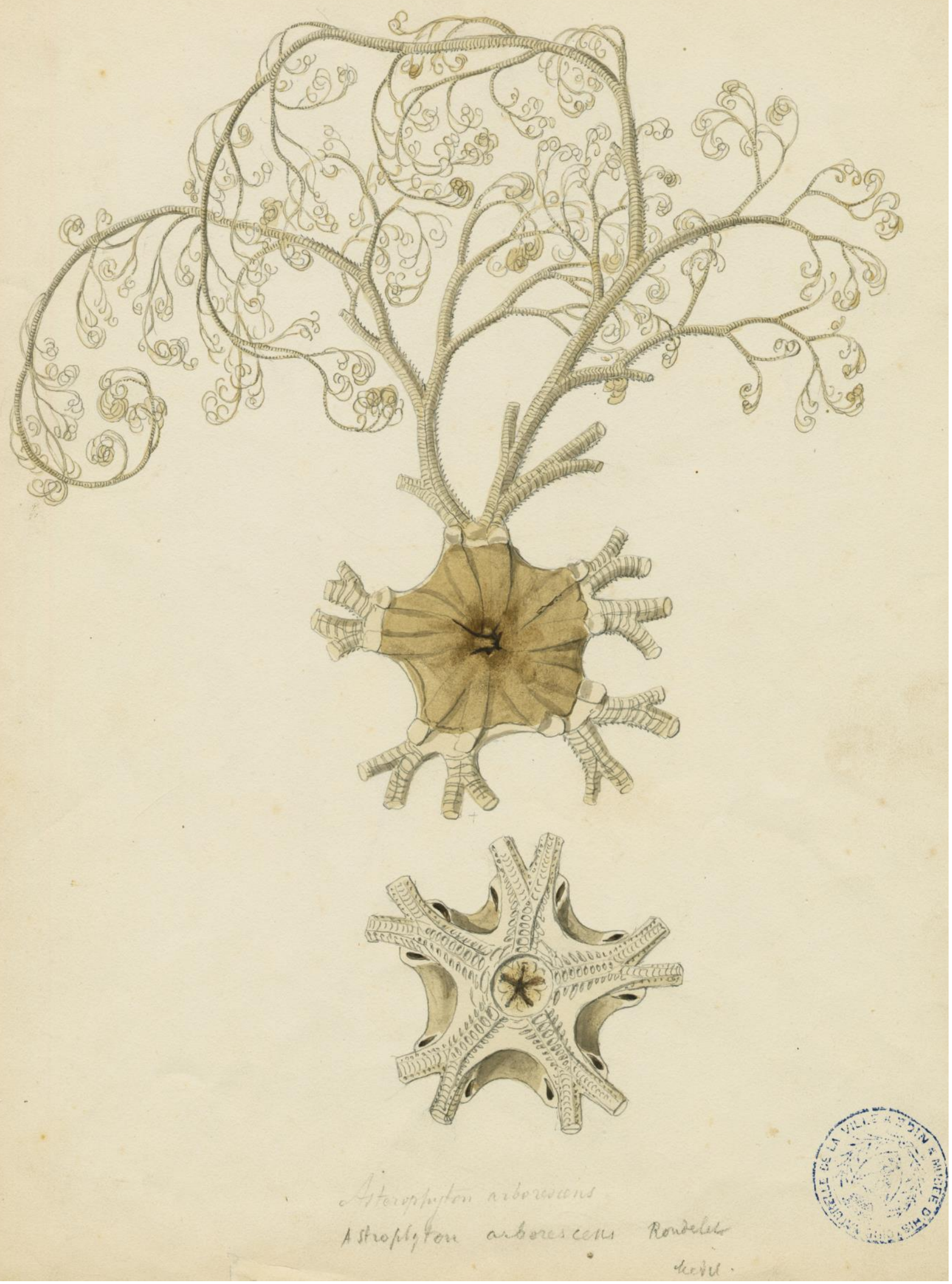

Fig. 13. The echinoderm Astrophyton arborescens. The painting is labeled April 21, 1879, a dried specimen. The actual dimensions of the painting are $35.3 \mathrm{~cm} \times 27 \mathrm{~cm}$. 


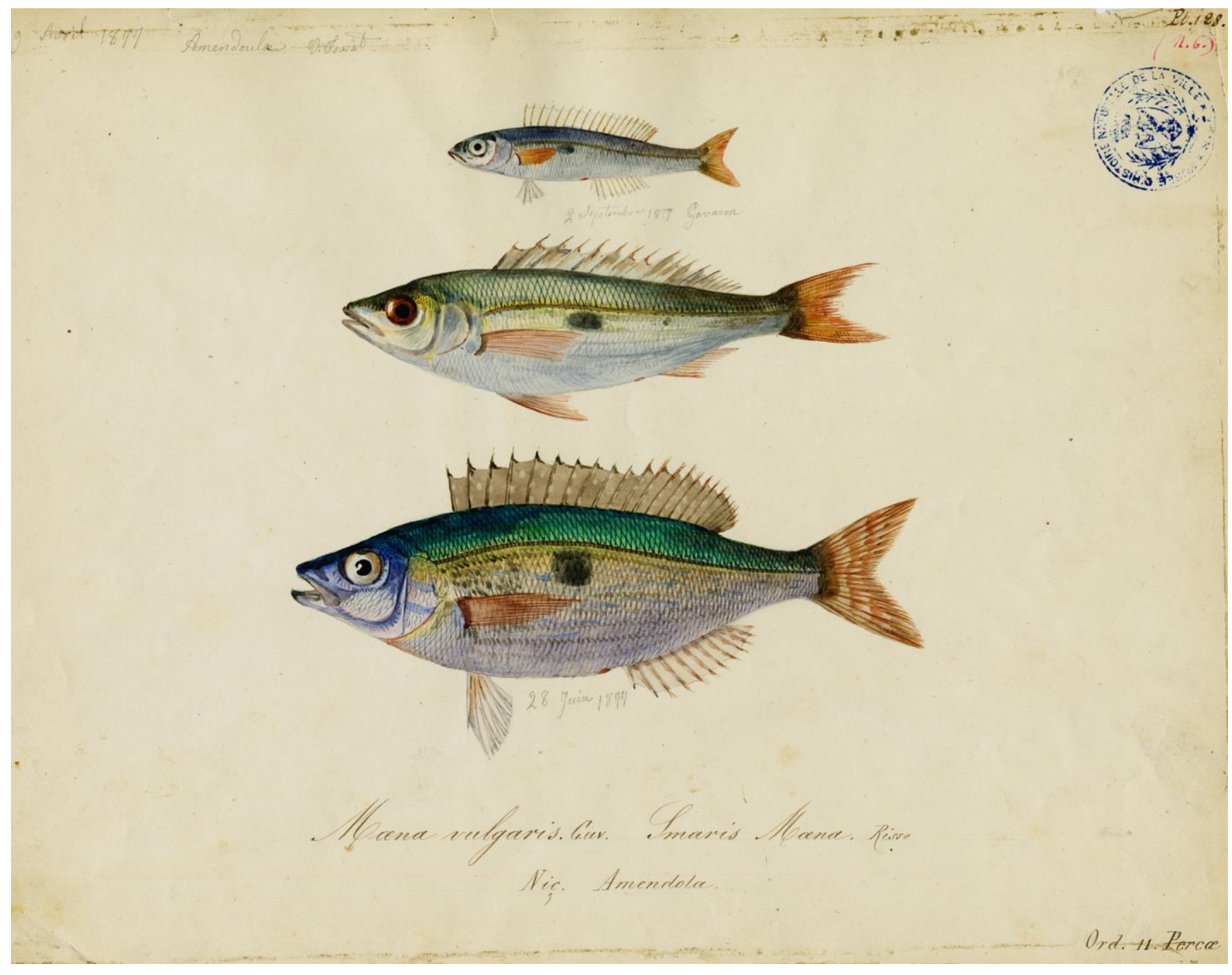

Fig. 14. The fish Spicara maena. According to the notation, the juvenile shown at the top was collected on September 2, 1877 and the adult at the bottom on June 28, 1877. The actual dimensions of the painting are $27 \mathrm{~cm} \times 35 \mathrm{~cm}$. 


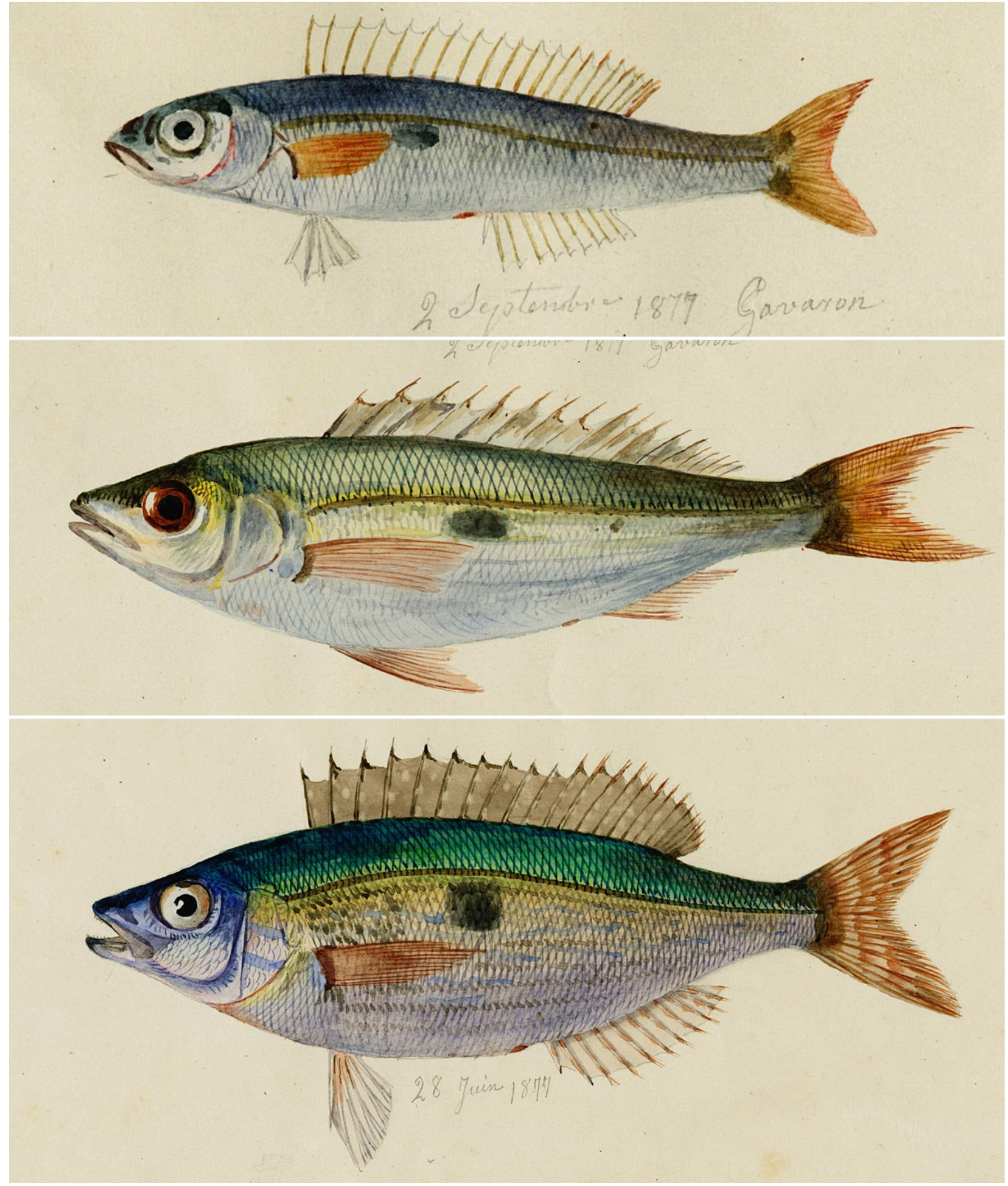

Fig. 15. Enlargements of images of the fish Spicara maena from the painting shown in figure 13 to show the details depected. The actual sizes of the specimens in the paintings (total lengths) from top to bottom are $8.1 \mathrm{~cm}, 15 \mathrm{~cm}$ and $18.3 \mathrm{~cm}$. 


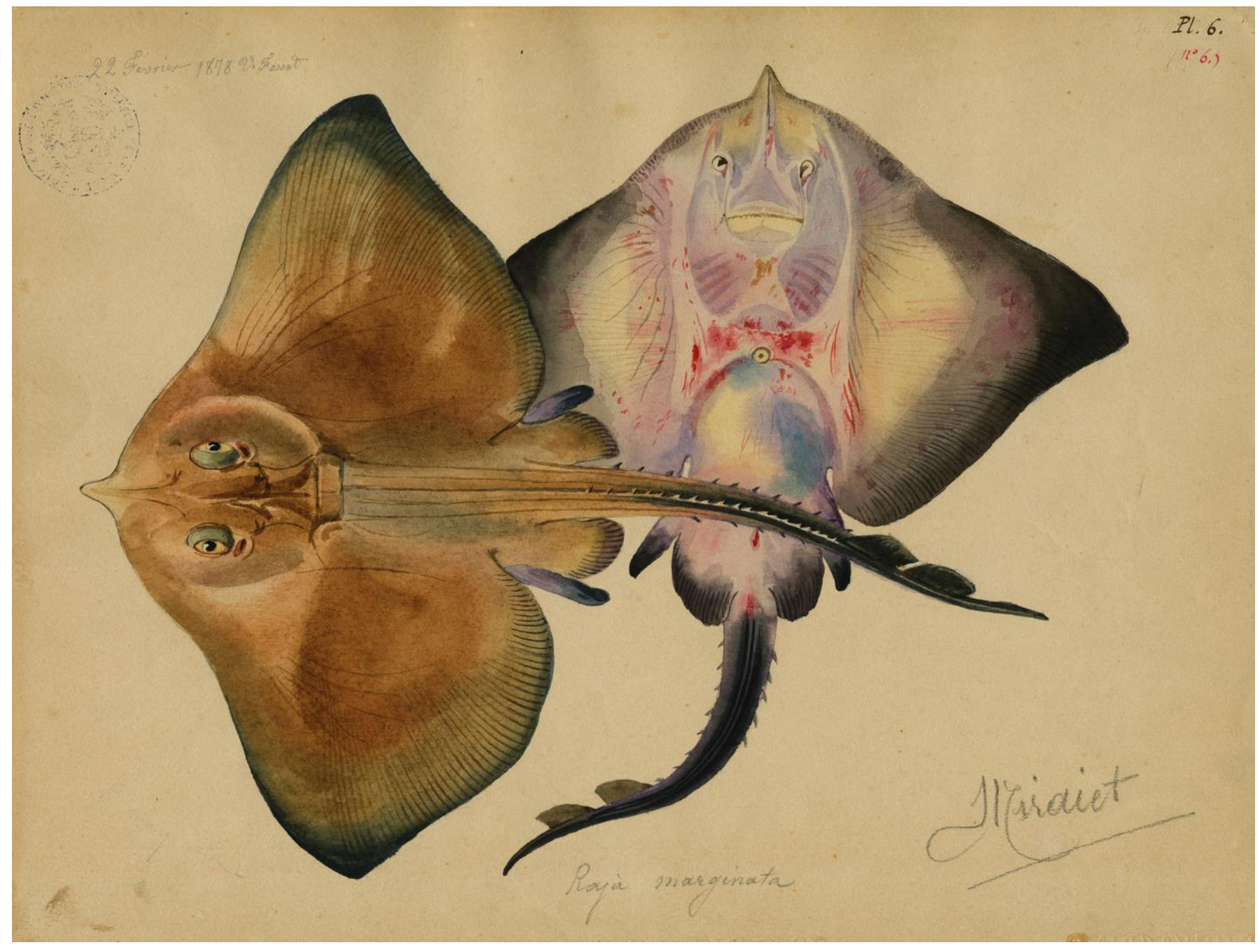

Fig. 16. The fish Raja alba from a specimen collected on February 22, 1878. The actual dimensions of the painting are $26.8 \mathrm{~cm} \times 35 \mathrm{~cm}$. 


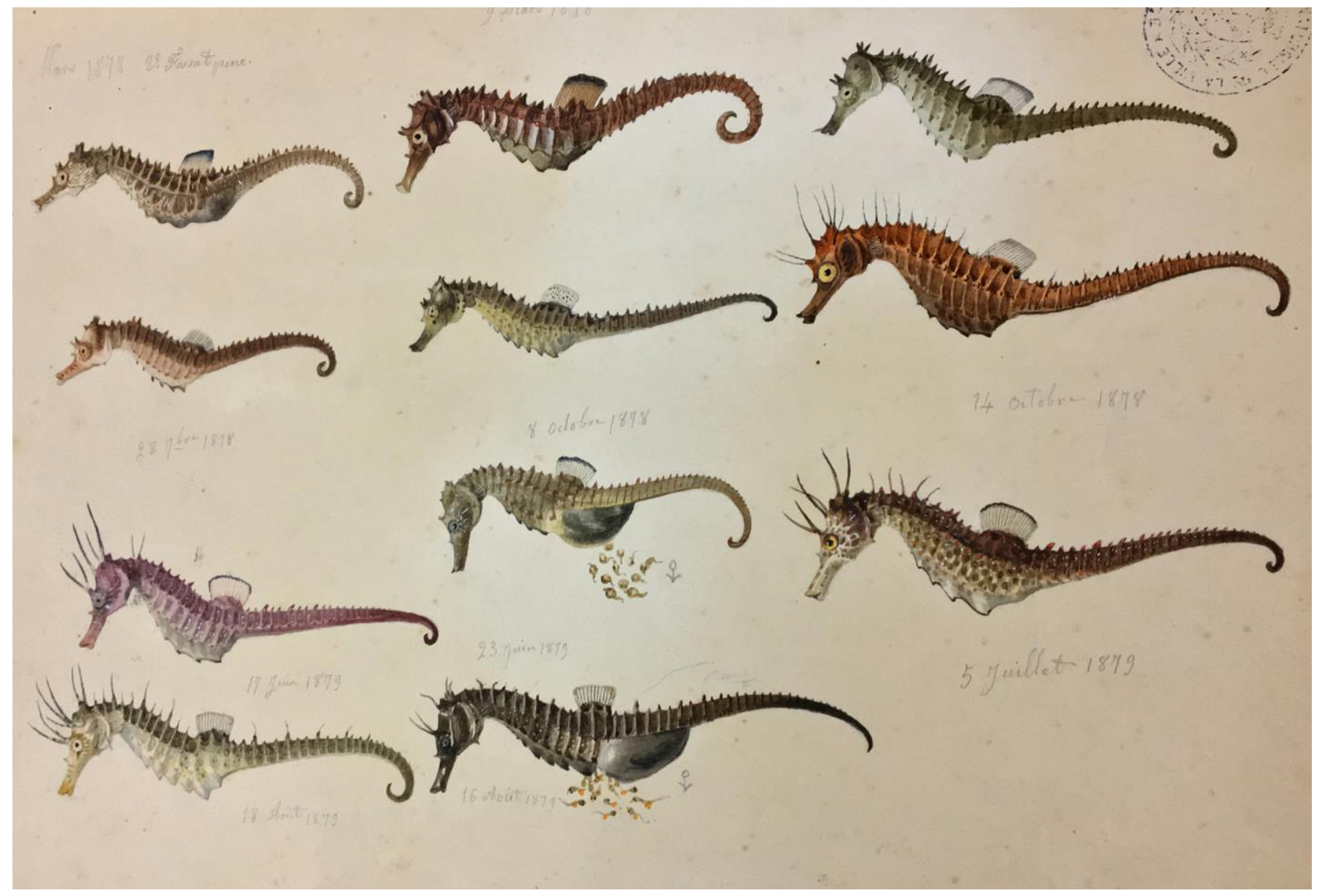

Fig. 17. The fish Hippocampus hippocampus collected on different dates, from left to right and top to bottom: March 2, 1878; March 2 1878; April 5, 1878; illegible; October 8, 1878; October 14, 1878; June 17, 1878; June 23, 1879; June 5, 1879; August 18, 1878; August 16, 1878. The actual dimensions of the painting are $26.8 \mathrm{~cm} \times 33 \mathrm{~cm}$. 


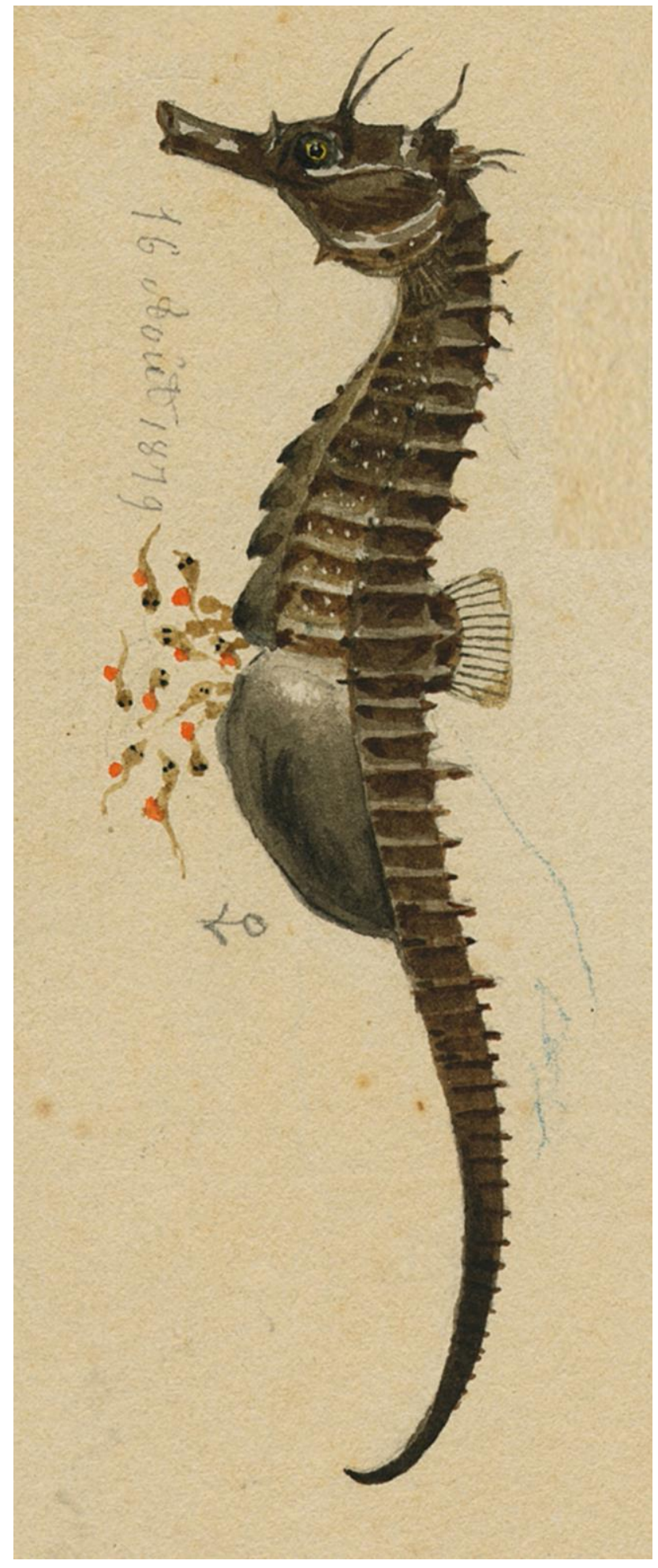

Fig. 18. Enlargement of the specimen of Hippocampus Hippocampus shown in figure 16 as collected on October 16, 1878. Clearly visible are the newly hatched larvae of the seahorse with their orange yolk sacs. The actual length of the specimen in the painting (tip of mouth to tail) is $10.2 \mathrm{~cm}$. 


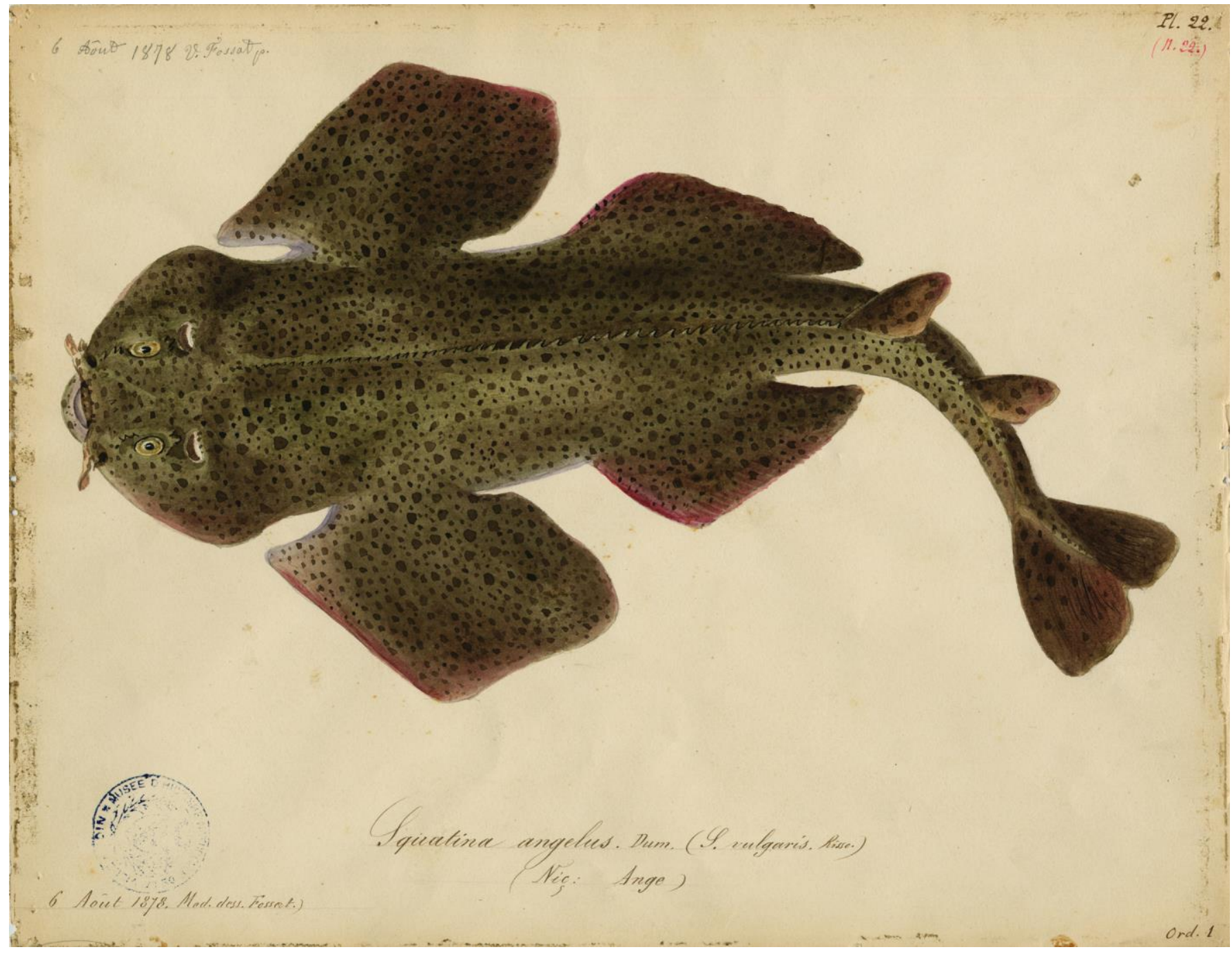

Fig. 19. The fish Squatina aculeata collected on August 6,1878 . The species listed today as among the sharks and stingrays in danger of extinction. The actual dimensions of the painting are $27.1 \mathrm{~cm} \times 35 \mathrm{~cm}$. 


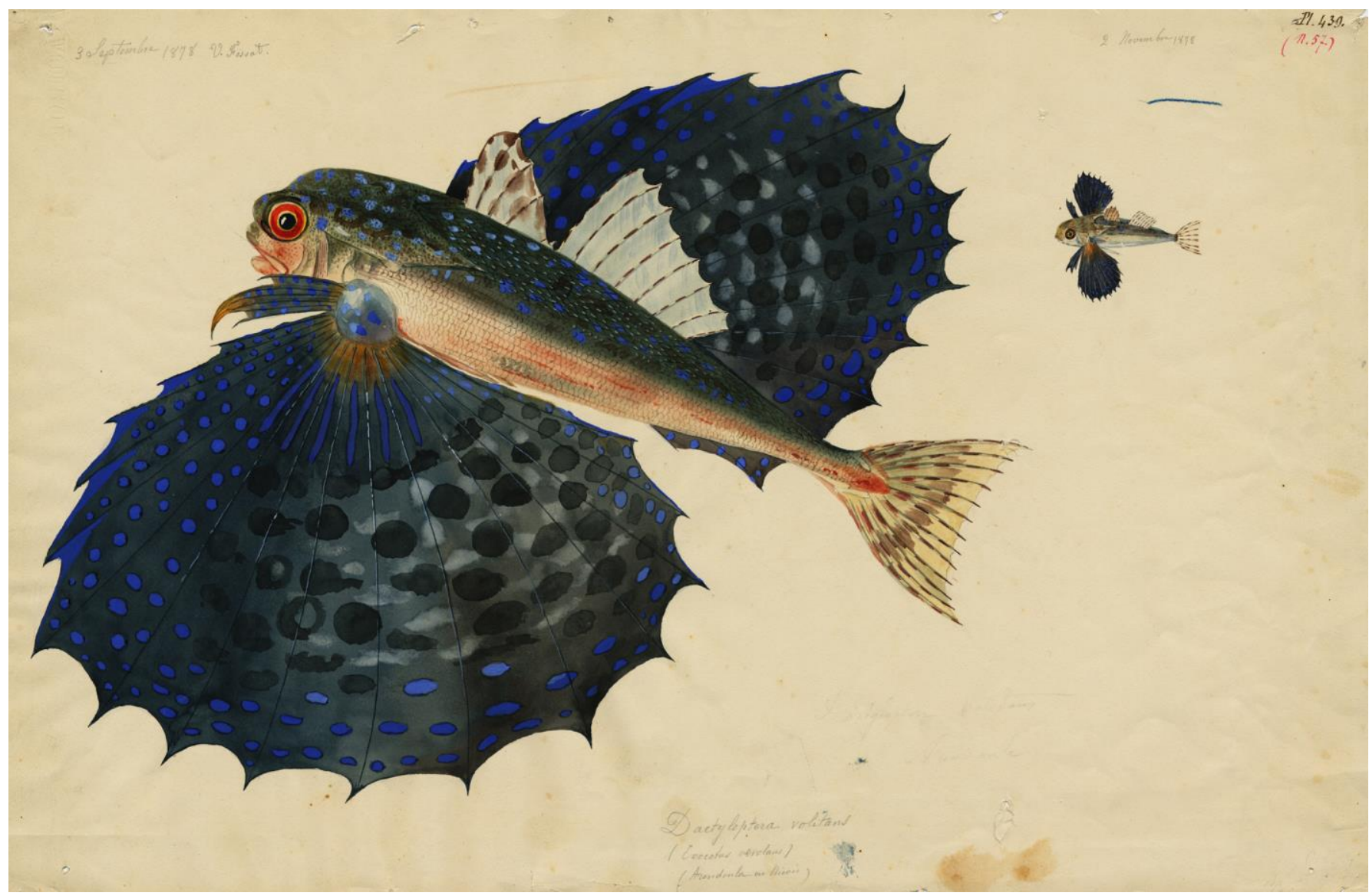

Fig. 20. The fish Dactylopterus volitans collected September 31878 (main adult specimen) and juvenile collected November 2, 1878. The actual dimensions of the painting are $35.5 \mathrm{~cm} \times 54 \mathrm{~cm}$. 


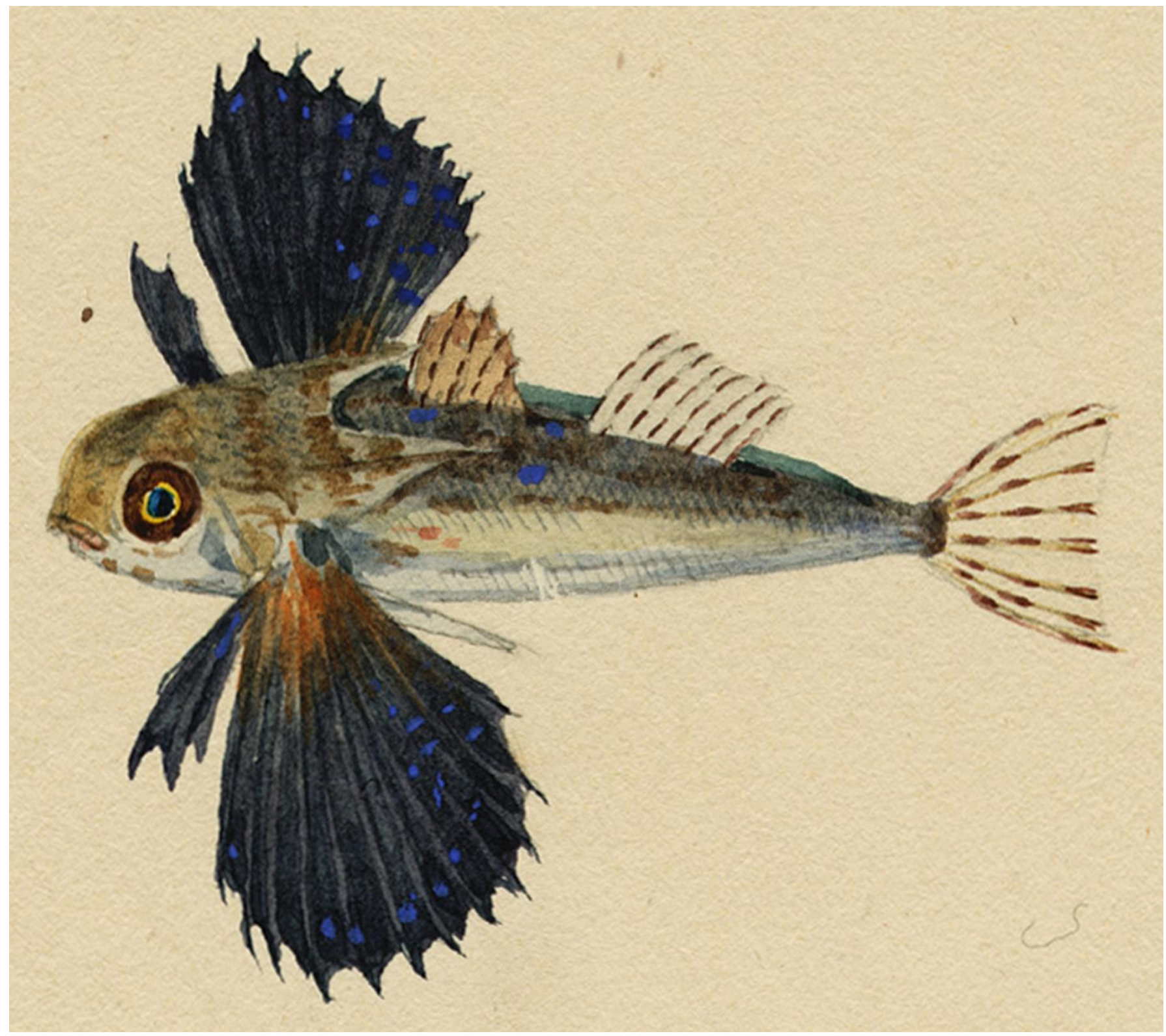

Fig. 21. Enlargement of the juvenile Dactylopterus volitans shown in figure 19. Actual size of the specimen in the painting (total length) is $5.5 \mathrm{~cm}$. 


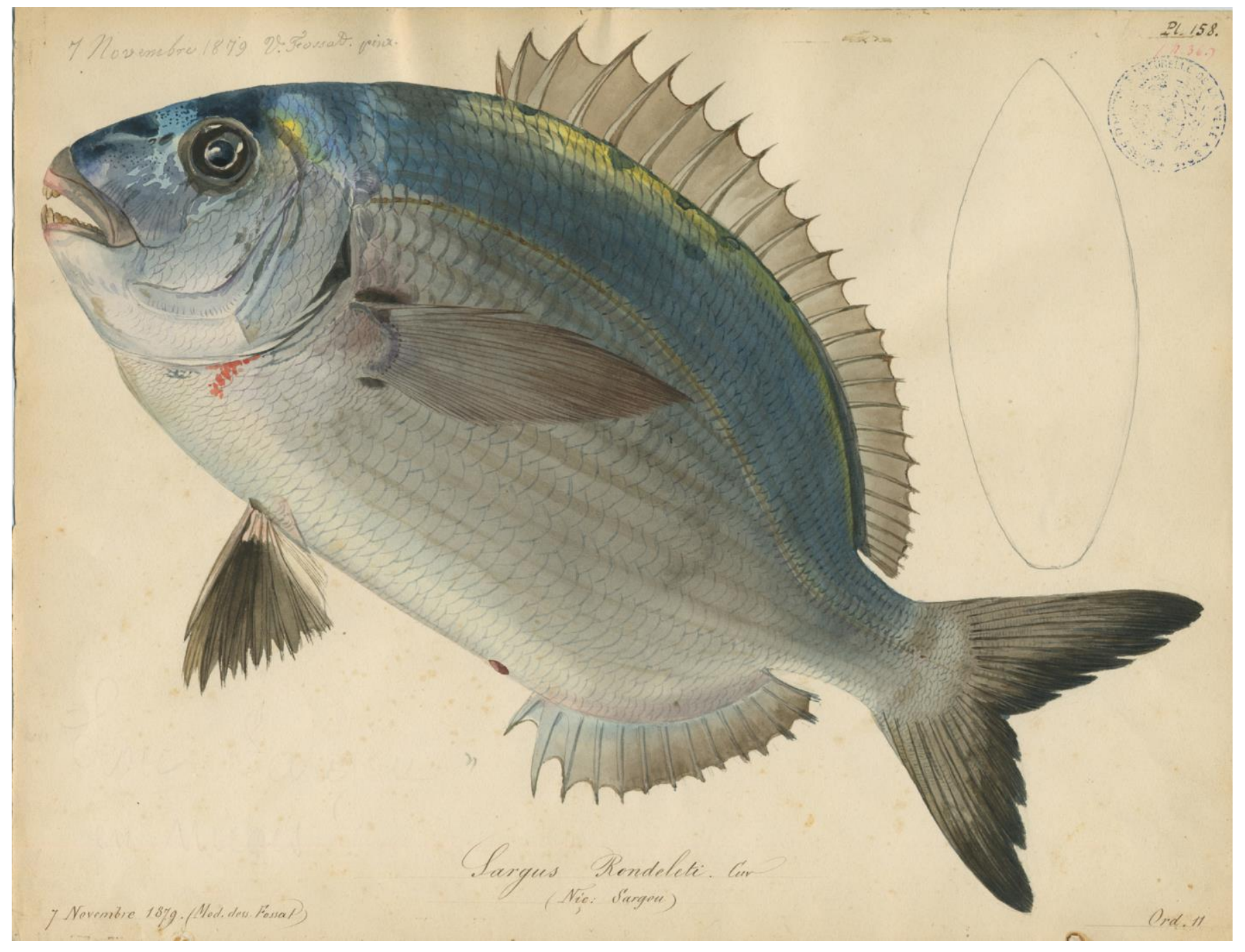

Fig. 22. The fish Diplodus sp. collected on November 7, 1879. The oval in the upper right shows the shape of the fish viewed head-on. The actual dimensions of the painting are $27 \mathrm{~cm} \times 35 \mathrm{~cm}$. 


\section{Acknowledgements}

Marie-Christine Maurel kindly invited me to write an article on Vincent Fossat. Jean-Paul Potron, Julie Carraut, Elise Hansen, and Robin Cauvin of the Musée Masséna kindly provided information and access to the works of Fossat held in the museum collections. Franck Rainaut kindly allowed reproduction of his painting of Vincent Fossat. Joëlle Defaÿ, formally of the Musée d'Histoire Naturelle de Nice, provided encouragement, access to documents, authorities, and patiently answered my questions. Without her aid, this manuscript would not have been possible. Olivier Gerriet of the Musée d'Histoire Naturelle de Nice provided the digital versions of the illustrations of Fossat's watercolors. The essential overall aid of the Musée d'Histoire Naturelle de Nice is gratefully acknowledged.

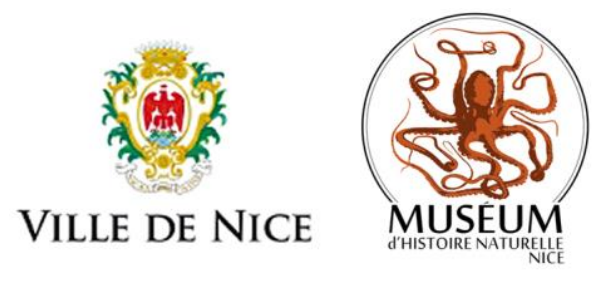

\section{References}

Anon. 1891. Nouvelles. Revue Mycologique, 13th Yr., N 49, Jan. 1, 1891, pg 99.

Anon. 1923. Un hommage au peintre Vincent Fossat. Le Matin, noํ12495, May 10, 1923: pg 4.

Bauchot, M.L.1996. Poissons de la mer de Nice peints par Vincent Fossat. Annales du Muséum d'Histoire Naturelle de Nice, 11:302-315.

Barla, J.-B. 1859. Les Champignons de la Province de Nice et Principlement les Especes Comestibles, Suspectes ou Vénéneuses Dessinés d'Apres Nature et Décrits. Nice: Imprimeries Canis Frères.

Barla, J.-B. 1868. Flore Illustrée de Nice et des Alpes-Maritimes. Iconographie des orchidées. Nice: Imprimerie Caisson et Mignon. https://gallica.bnf.fr/ark:/12148/bpt6k1025010n.texteImage

Barla, J.-B. 1876. Description et Figure du Xanthium Spinosum Lampourde Epineuse Spécifique contre l'Hydrophie. Nice: Imprimerie Caisson et Mignon.

Barla, J.-B. 1888. Flore Mycologique Illustrée les Champignins des Alpes-Martimes avec l'Indication de leurs propriétés utiles ou nuisibles. Nice: A. Gilletta.

Barla, J.-B. 1889a. Flore Mycologique Illustrée les Champignins des Alpes-Martimes aved l'Indication de leurs propriétés utiles ou nuisibles, 2, Gen. II. Lepiota.

Barla, J.-B. 1889b. Flore Mycologique Illustrée les Champignins des Alpes-Martimes aved l'Indication de leurs propriétés utiles ou nuisibles, 3, Gen. III. Armilaria. Nice: A. Gilletta.

Barla, J.-B. 1890. Flore Mycologique Illustrée les Champignins des Alpes-Martimes aved l'Indication de leurs propriétés utiles ou nuisibles, 4 \& 5, Gen. IV. Tricholoma. Nice: A. Gilletta.

Barla, J.-B. 1892. Flore Mycologique Illustrée les Champignins des Alpes-Martimes aved l'Indication de leurs propriétés utiles ou nuisibles, 6 , Gen. V. Clitocybe. Nice: A. Gilletta.

Beltrutti 1996a. Vincent Etienne Fossat 1822-1891. Annales du Muséum d'Histoire Naturelle de Nice, 11:51-54.

Beltrutti 1996b Biographie généalogique concernant Jean-Baptiste Barla. . Annales du Muséum d'Histoire Naturelle de Nice, 11:19-50.

Caziot, E. 1918. Notes biographiques de J.-B. Barla. Riviera Scientifique, Year 5, 113-125.

Chamagne Rollier, B., Defaÿ, J. 2013. Le Cabinet de Curiosités d'un Naturaliste du XIXe Siécle. Nice: Editions Gilletta Nice Matin.

Cuccuini, P. 2009. I funghi di Jean-Baptiste Barla, artista e naturalista. Il Museo di Storia Naturale dell'Università di Firenze, 2, 245-251. 
Defaÿ, J. 1998. Vincent Fossat 1822-1891. in Acadèmia Nissarda, Le Pays de Nice et ses Peintres au XIXè Siecle. Nice: Acadèmia Nissardia.

Fighiera, E. 1912. Le peintre Louis Garneray à Nice. Nice Historique, 15th year, no. 3 (March), 117-123

Fredj, G., Meinardi, M. 2007. L'Ange et l'Orchidée. Nice: Serre Editeur.

Isnard, P., Cordier, P. 1935. Le Musée d'Histoire Naturelle de Nice. La Terre et la Vie, 10:123-128.

Lavagna, J. 1914. Au musée d'histoire naturelle de Nice: Une exposition d'aquarelles. Riveria Scientifique, Year 1, January, 7-8.

Monot, J. 2011. Les Pêches Méditerranéenes, Voyage dans les Traditions. Versailles: Editions Quae.

Thevenon, L. 1990. Les musées de Nice (1925-1965). Nice Historique, year 1990, 110-120.

Trimbach, J. 1996. Barla et la mycologie. Annales du Muséum d'Histoire Naturelle de Nice, 11:179-256.

WWF/IUCN (2004). The Mediterranean deep-sea ecosystems: an overview of their diversity, structure, functioning and anthropogenic impacts, with a proposal for conservation. IUCN, Málaga and WWF, Rome. 